\title{
What is There in a 'Like'? Political Content in Facebook and Instagram in The 2019 Valencian Regional Election*
}

\author{
Silvia Marcos García \\ UNIVERSITAT JAUME I DE CASTELLÓ \\ smarcos\&uji.es \\ ORCID: 0000-0003-1682-1009
}

\section{Nadia Viounnikoff-Benet \\ UNIVERSITAT JAUME I DE CASTELLÓ}

nbenet/िuji.es

ORCID. 0000-0001-6741-9728

\section{Andreu Casero Ripollés}

UNIVERSITAT JAUME I DE CASTELLÓ

casero\&uji.es

ORCID. 0000-0001-6986-4163

Received: 14/10/2019

Accepted: 20/03/2020

\begin{abstract}
Over the last few years, social networks such as Facebook and Instagram have become the preferred places for political communication. On the one hand, politicians have incorporated them into their strategy as a channel through which they can share their messages. On the other hand, users have a space where they can take part and show their interest in political issues. This paper examines posts on Facebook and Instagram by the main Valencian political parties and their respective leaders in the election campaign. We analysed the nature of the content and users' 'likes' to reveal the functions and themes of the most popular posts and the use made of visual resources and interaction tools. The results show that the positioning taken by politicians influences the content getting the most 'likes'. While supporters of opposition parties are most pleased by critical messages, followers of pro-government parties prefer messages that focus on management success. At the same time, items focusing on social policies and election campaign issues are those that generate the most 'likes' among the public. Visual aids (such as photographs and videos) and hash tags and links help boost users' approval.
\end{abstract}

Keywords: political communication, election campaign, Valencian Community, social media, Facebook, Instagram.

\footnotetext{
* Acknowledgements: This paper is linked to Research Project UJI-B2017-55 funded by Universitat Jaume I de Castelló within Spain's Research Promotion Plan (PPI) 2017.
} 
Corresponding author: Silvia Marcos García. Facultat de Ciències Humanes i Socials. Av. de Vicent Sos Baynat s/n, 12071 Castelló de la Plana (Spain).

Suggested citation: Marcos García, S. et al. (2020). What is There in a 'Like'? Political Content in Facebook and Instagram in The 2019 Valencian Regional Election. Debats. Journal on Culture, Power and Society, 5, 85-109. DOI: http://doi.org/10.28939/iam.debats-en.2020-5

\section{INTRODUCTION}

Over the last few years, social media have come to play a major role in political communication (Vaccari, 2017; Rúas Araujo and Casero Ripollés, 2018). In this context, many studies take a sceptical view of social networks, arguing that they have not become institutionalised and that they spawn greater complexity in political negotiations (Mancini, 2013). They also argue that digital actions and activities have little impact on traditional political management and decision-making circles (Morozov, 2011; Christensen and Bengtsson, 2011). Nevertheless, other authors point to the communication potential of these platforms, which politicians now often use for communicating with citizens in digital settings (McNair, 2011; Chadwick, 2013; Casero Ripollés et al., 2016). On the one hand, social networks help parties and politicians directly link to the online audience in a direct, familiar manner, dispensing with the mainstream media's 'man-in-the-middle' role (Jenkins, 2006). On the other hand, social media users play a more active part and are no longer mere passive consumers of information. That is because they produce their own information, content, freely give their views, and speak of their interests (Díaz, 2014; Micó and Casero Ripollés, 2014).

Social networks such as Facebook and Instagram have become major players in the political communication field. They are currently the two platforms with the most audience traffic, with over 2,000 million and 1,000 million users a month, respectively (Hootsuite, 2019). Likewise, recent studies show that Spanish leaders and parties now use both networks in their online communication strategies (Abejón et al., 2012; Fenoll and Cano Orón, 2017; Marcos García and Alonso Muñoz, 2017; Selva Ruíz and Caro Castaño, 2017; López
Rabadán and Doménech Fabregat, 2018). Earlier literature on the subject reveals that both platforms help mobilise the electorate, promote parties, and facilitate the strategic presentation of candidates and the forging of stronger links between politicians and citizens (Enli and Skogerbø, 2013; Giansante, 2015; Filimonov et al., 2016). Nevertheless, little is known about how citizens use these social networks given that there are few studies on the subject.

To shed new light on how Facebook and Instagram are used in the political sphere, this study compares the content of posts on Facebook and Instagram by the main parties in The Valencian Country, and by their respective leaders during the 2019 Regional Election. The study also gauges the impact of these posts on the general public. Specifically, the goal was to discover which post content spawned the most 'likes' among users.

The Valencian Regional Election was unusual in that it coincided with the appearance of new political parties and the fragmentation of the vote. This made it impossible for any single party to obtain an absolute majority and govern on its own - a context that is particularly interesting from the political communication standpoint.

\section{FACEBOOK AND INSTAGRAM AS LEADING SOCIAL NETWORKS IN THE POLITICAL COMMUNICATION FIELD}

Over the last decade, digital tools have been steadily incorporated in the political field. As a result, parties and politicians have been forced to make their communication strategies dovetail with the Internet 
(Kreiss, 2012). Right now, party use of digital resources has become a natural, daily occurrence (Stromer Galley, 2014; Lilleker et al., 2015), and part and parcel of election campaign strategies (Castillejo and Semova, 2012; García et al., 2012).

Since the beginning of its use in political communication, Twitter has been seen as one of the key social networks in the virtual politics field (Jungherr, 2014; Kruikemeier, 2014). This is why many researchers have studied: (1) the politicians' diverse goals on Twitter (Rahat and Sheafer, 2007; Parmelee and Bichard, 2011; López Meri et al., 2017); (2) the commonest issues on the social network (Zugasti Azagra and Pérez González, 2016; López García, 2016; Alonso Muñoz and Casero Ripollés, 2018); (3) the use of visual resources (Quevedo et al., 2016); (4) interaction (Miquel Segarra et al., 2017).

The large number of users of social networks such as Facebook and Instagram also makes these platforms attractive for politicians. Both platforms are increasingly used by parties and their respective politicians as channels for forging closer links with their voters (Abejón et al., 2012; Fenoll and Cano Orón, 2015; Marcos García and Alonso Muñoz, 2016; Selva Ruíz and Caro Castaño, 2017). Such use was consolidated after the 2015 and 2016 Spanish General Elections (Abejón Mendoza and Mayoral Sánchez, 2017; Quevedo Redondo and Portalés Oliva, 2017).

Studies such as those by Magin et al. (2017) show that Facebook is a kind of feedback channel that lets parties strike up conversations with the electorate. This feature, together with this social network's gift for creating and organising communities (Casero Ripollés, 2018) fosters political involvement (Di Bonito, 2014). Likewise, the platform's many applications boost the dissemination of electoral information (Magin et al., 2017) and the promotion of political players (Enli and Skogerbø, 2013), forging stronger links with citizens (Giansante, 2015). Recent studies reveal that the addition of new tools for interaction in 2016 helps users show their emotional reaction to content. This makes Facebook useful for getting a better grasp of the electorate's emotions (Coromina et al., 2018).
Instagram has led a change in the way social networks are used, with visual elements (photos, videos, emoticons) becoming ever more common in users' communication strategies (Svensson and Russmann, 2017).

The incorporation of these tools in communication strategies is driving new ways of personalising content (Enli and Skogerbø, 2013; Bentivegna, 2015; López Rabadán and Doménech Fabregat, 2018). In particular, Instagram's individualisation features let one build a much more spontaneous and human image of a political leader, making it much easier for him or her to forge a personal relationship with users (Selva Ruíz and Caro Castaño, 2017; Viounnikoff-Benet, 2018).

Given social media's huge scope, the main studies on such networks have focused on how politicians exploit these platforms in their communication strategies. Yet while some authors have stressed the important role played here by citizens (Fenoll and Cano Orón, 2017; Coromina et al., 2018), research in this field is still thin on the ground.

\section{SOCIAL NETWORKS AS AN ARENA FOR CITIZEN PARTICIPATION}

One of the key features of social networks is the scope for citizens to freely take part in political debate. These digital media turn formerly passive consumers into active users who can create their own content, and express their own views on and interest in political issues (Jenkins 2006; Micó and Casero Ripollés, 2014).

Tools found on these platforms - such as mentions (@), strongly favour new contact channels among users, who can directly answer questions (which may be asked of users fitting a given profile) or hold a conversation (Larsson, 2015). However, earlier studies have shown that limited use is made of this kind of tool in political debates, whether by politicians or citizens themselves (Alonso Muñoz et al., 2016; Marcos García et al., 2017).

Nevertheless, there are other kinds of selective interaction tools that, while they do not foster conversations 
among users, do show how users feel about the content (Miquel Segarra, el al., 2017). Here, 'likes' appear on both Facebook and Instagram, allowing users to link content published by others and, of course, to say whether they like (or dislike) certain publications (Larsson, 2015; Coromina et al., 2018).

Up until now, studies in this field show that political parties often use visual media - especially photos - (Fenoll and Hassler, 2019) because these are most effective for grabbing users' attention (ViounnikoffBenet, 2018). Links are another thing fostering user interaction (Miquel Segarra et al., 2017). That said, we know almost nothing about the kinds of message and content that make the greatest impact on users.

\section{THE 2019 REGIONAL ELECTIONS IN THE VALENCIAN COUNTRY}

Studies in Spain on social networks and election campaigns have mainly focused on national elections. By contrast, research on regional, municipal, and European elections is very sparse. Here, one should note a study on the 2009 and 2012 Basque elections (Cebrián Guinovart et al., 2013; Pérez et al. 2014); the 2011 and 2015 Madrid elections (Fernández Muñoz and Arceo Vacas, 2015; Marcos García and Alonso Muñoz, 2019), and another on the 2010, 2011, and 2015 Catalan elections (Di Bonito, 2014; López Meri, 2016). In the case of regional elections in The Valencian Country, two notable studies are those by Gamir Ríos (2016) and by López García et al. (2016) on Twitter and on the setting of a thematic agenda.

The Valencian Country's Regional Election was held on the $28^{\text {th }}$ of April 2019. It was unusual in that it coincided with the appearance of new political parties and the fragmentation of the vote. These new parties included Unides Podem and Ciudadanos (which first appeared in the 2015 election) and were joined by the more recent Vox. The large number of parties meant no single one could obtain an absolute majority. The result was a lengthy period of negotiations after the election before a coalition government was finally formed. In this sense, it was a repeat of what happened after the 2015 Regional Election.

\section{RESEARCH AIM}

The aim of this study is to analyse the posts/publications on Facebook and Instagram by the main political parties in The Valencian Country and to discover the features of those garnering the most 'likes' among users. Here, we seek to answer the following research questions:

Q1: What functions did the themes covered perform and what visual and interaction resources garnered the most 'likes' among the posts/ publications by politicians?

Q2: Was role did the following factors play in the number of 'likes'? - (1) Ideological considerations; (2) The party's track record (whether long-established or emergent); (3) The party's position in government or in opposition.

\section{METHODOLOGY}

\section{Sample}

The sample for this study was extracted from The Valencian Country's Regional Election held on the $28^{\text {th }}$ of April 2019 and focused on the Facebook and Instagram sites of the six main political parties: Partido Popular (PP); Partido Socialista (PSPV-PSOE); Compromís; Unides Podem; Ciudadanos (Cs); Vox (and their respective candidates: Isabel Bonig, Ximo Puig, Mónica Oltra, Rubén M. Dalmau, Toni Cantó). The Vox candidate, José María Llanos, was not included in the analysis because he had no publications on Facebook and only one on Instagram during the chosen period. The analysis covered the period spanning the fifteen official days of the campaign, the so-called 'Day of Reflection' before Voting Day, Voting Day itself and the day following it.

Specifically, the corpus of the study comprises posts on Facebook and Instagram getting more than the 
Table 1 Number of posts selected for each party/candidate in each social network

\begin{tabular}{|c|c|c|c|c|c|c|}
\hline \multirow{3}{*}{$\begin{array}{l}\text { Party / Candidate } \\
\text { PPCV }\end{array}$} & \multicolumn{2}{|c|}{ Total $N^{\circ}$ of posts } & \multicolumn{2}{|c|}{$\begin{array}{c}\text { Average } \mathrm{N}^{\circ} \text { of 'likes' } \\
\text { (Total } \mathrm{n}^{\circ} \text { 'likes' / Total } \mathrm{n}^{\circ} \\
\text { posts by party) }\end{array}$} & \multicolumn{2}{|c|}{$\begin{array}{c}\mathbf{N}^{\circ} \text { of posts with 'likes' } \\
\text { above the average }\end{array}$} \\
\hline & FB & IG & $\mathrm{FB}$ & IG & $\mathrm{FB}$ & IG \\
\hline & 66 & 29 & 30.33 & 64 & 26 & 12 \\
\hline \multirow[t]{2}{*}{ PSPV-PSOE } & FB & $I G$ & $\mathrm{FB}$ & $I G$ & $\mathrm{FB}$ & IG \\
\hline & 61 & 39 & 204.88 & 114 & 22 & 17 \\
\hline \multirow[t]{2}{*}{ Compromís } & $\mathrm{FB}$ & IG & $\mathrm{FB}$ & IG & FB & IG \\
\hline & 68 & 51 & 476.38 & 636 & 21 & 21 \\
\hline \multirow[t]{2}{*}{ Unides Podem } & FB & IG & $\mathrm{FB}$ & IG & FB & IG \\
\hline & 78 & 36 & 86.57 & 109 & 14 & 12 \\
\hline \multirow[t]{2}{*}{ Cs } & FB & IG & $\mathrm{FB}$ & IG & FB & IG \\
\hline & 40 & 20 & 68.32 & 110 & 11 & 7 \\
\hline \multirow[t]{2}{*}{ Vox } & FB & IG & $\mathrm{FB}$ & IG & $\mathrm{FB}$ & IG \\
\hline & 76 & 35 & 213.96 & 591 & 32 & 14 \\
\hline \multirow[t]{2}{*}{ Bonig } & $\mathrm{FB}$ & IG & $\mathrm{FB}$ & IG & FB & IG \\
\hline & 77 & 39 & 67.94 & 214 & 21 & 17 \\
\hline \multirow[t]{2}{*}{ Puig } & FB & IG & $\mathrm{FB}$ & IG & FB & IG \\
\hline & 63 & 32 & 170.22 & 195 & 15 & 10 \\
\hline \multirow[t]{2}{*}{ Oltra } & FB & IG & $\mathrm{FB}$ & IG & $\mathrm{FB}$ & IG \\
\hline & 49 & 27 & 562.53 & 963 & 19 & 7 \\
\hline \multirow[t]{2}{*}{ Dalmau } & FB & IG & FB & IG & $\mathrm{FB}$ & IG \\
\hline & 75 & 15 & 162.13 & 80 & 28 & 7 \\
\hline \multirow[t]{2}{*}{ Cantó } & $\mathrm{FB}$ & IG & FB & $I G$ & FB & IG \\
\hline & & 9 & 225.71 & 613 & 11 & 3 \\
\hline \multicolumn{5}{|c|}{ TOTAL by network } & 220 & 127 \\
\hline & & & \multicolumn{2}{|c|}{ TOTAL posts analysed } & \multicolumn{2}{|c|}{347} \\
\hline
\end{tabular}


average number of 'likes' for each of the profiles of the selected political players. We chose the number of post 'likes' as the basis for inclusion in our sample bearing in mind that this is a common benchmark in social networks. Furthermore, it is a simple measure and also happens to be the one most used to express interest in those posts that get most users' attention (Larsson, 2015; Coromina et al., 2018). Studying these messages sheds light on which features and elements typify the posts getting the most 'likes'. Thus, of 1027 posts shared by the six parties and their respective candidates on Facebook and Instagram during the eighteen days covered by our study, we focused on 347 posts making up $33.78 \%$ of the total sample (see Table 1).

The selection of the political parties making up the sample was based on two criteria: (1) a party's representativeness; (2) a party's track record. There were six parties that between them accounted for $95.43 \%$ of the votes cast. PP, PSPV-PSOE, and Compromís had the longest track records in The Valencian Country. The three upstarts were Unides Podem, Vox, and C's. Vox's case is particularly interesting for it had no seats in the Valencian Parliament. The 2019 election allows one to compare the strategies used by traditional parties and leaders with the upstarts on the regional scene.

\section{Tools}

To meet our research goal and answer the questions raised, we used a methodology based on quantitative content. This let us conduct a descriptive analysis that was both objective and systematic (Igartua, 2006) in covering the features of the posts that garnered most 'likes'. Posts in both the social networks were manually analysed by two coders and the inter-coding reliability achieved was 0.98 using Scott's Pi coefficient.

A special analytical model was drawn up and tailored to the study goal, which was tackled under two broad heads.

The first level covers the function and theme of the messages posted by political players (Table 2 ).
The second level analyses the visual resources used and their type, context, and key elements. The spotlight is also shone on the interaction tools offered by Facebook and Instagram: mentions, hash tags, and links (Table 3).

\section{Results}

Our analysis of the posts selected in this study lets us identify various trends in functions, themes, visual resources, and the parties/politicians' posts that have generated most 'likes' on Facebook and Instagram.

Functions with most 'likes' among Facebook and Instagram users If we focus on the posting function, the data show that the posts getting most 'likes' were directly linked to the party or the candidate's position in the Regional Government. In the case of Opposition politicians (PP, Cs, Vox), the posts that got the most 'likes' on Facebook were those critical of political opponents, especially those slating parties and candidates in the government (Table 3). Specifically, the greatest numbers of likes for the PP party/candidates (42.31\%) were for Isabel Bonig (38.10\%) and Toni Cantó (45.45\%). The second greatest number of likes was for Ciudadanos (27.27\%) and Vox (18.75\%). In Vox's case, the posts garnering most 'likes' were those sharing things on the agenda and information on the various campaign events (25\%). In Ciudadanos' case, they were manifesto promises (45.4\%) (Table 4).

However, the pattern was different on Instagram, where users showed diverse interests (Table 4). Almost half the 'likes' from Vox followers (42.86\%) and PP followers $(41.67 \%)$ came from posts covering the agenda of campaign events and visits. In Isabel Bonig's case, the posts spurring most 'likes' were those in which the candidate shared her proposals with users.

Different lessons can be learnt from the data on Ciudadanos and its leader, Toni Cantó. Party followers were mainly interested in those posts in which a given person or event was thanked (42.85\%) or in which the electorate's participation was sought, either directly by asking for citizens' votes, or asking the public to attend campaign events (28.57\%). In Cantó's case, 


\section{Table 2 Protocol for analysing functions and themes}

\begin{tabular}{|c|c|c|c|}
\hline \multicolumn{2}{|r|}{ Function } & \multicolumn{2}{|r|}{ Theme } \\
\hline Agenda & $\begin{array}{l}\text { Posts with information covering spe- } \\
\text { cific campaign events. }\end{array}$ & Economy & $\begin{array}{l}\text { Posts on jobs, unemployment, } \\
\text { wages, public deficit, public spend- } \\
\text { ing, debt, the crisis, taxes, entrepre- } \\
\text { neurship, etc. }\end{array}$ \\
\hline $\begin{array}{l}\text { Manifesto or } \\
\text { promises }\end{array}$ & $\begin{array}{l}\text { Posts on manifesto proposals, } \\
\text { wishes, and views }\end{array}$ & Social Policy & $\begin{array}{l}\text { Posts on pensions, Health, Educa- } \\
\text { tion, The Welfare State, social jus- } \\
\text { tice, equality, immigration, etc. }\end{array}$ \\
\hline $\begin{array}{l}\text { Political } \\
\text { achievements } \\
\text { in government } \\
\text { or in } \\
\text { opposition }\end{array}$ & $\begin{array}{l}\text { Posts praising the party's and/or } \\
\text { leader's achievements }\end{array}$ & $\begin{array}{l}\text { Culture \& } \\
\text { Sport }\end{array}$ & $\begin{array}{l}\text { Posts on cultural industries (cinema, } \\
\text { literature, art, etc.) and sport }\end{array}$ \\
\hline $\begin{array}{l}\text { Criticism of } \\
\text { opponents }\end{array}$ & $\begin{array}{l}\text { Posts explicitly attacking opponents, } \\
\text { their manifestos, deeds, and ideol- } \\
\text { ogy }\end{array}$ & $\begin{array}{l}\text { Science \& } \\
\text { Technology }\end{array}$ & $\begin{array}{l}\text { Posts on R\&D, data infrastructure } \\
\text { (optic fibre, ADSL, Wi-Fi), etc. }\end{array}$ \\
\hline $\begin{array}{l}\text { Media } \\
\text { Information }\end{array}$ & $\begin{array}{l}\text { Posts sharing media content featur- } \\
\text { ing the party or leader }\end{array}$ & Infrastructure & $\begin{array}{l}\text { Posts on transport services and } \\
\text { infrastructure, such as roads }\end{array}$ \\
\hline Interaction & $\begin{array}{l}\text { Posts in which the party or leader } \\
\text { responds to a user or raises a ques- } \\
\text { tion for followers }\end{array}$ & Corruption & $\begin{array}{l}\text { Posts on political and/or corporate } \\
\text { corruption }\end{array}$ \\
\hline Participation & $\begin{array}{l}\text { Posts that directly call for a vote, call } \\
\text { for donations and the mobilisation of } \\
\text { volunteers }\end{array}$ & $\begin{array}{l}\text { Democratic } \\
\text { Renewal }\end{array}$ & $\begin{array}{l}\text { Posts that cover the need for demo- } \\
\text { cratic renewal or to change certain } \\
\text { things or Spain's Election Act; } \\
\text { messages on Francoism, 'historic } \\
\text { memory' defence of The Spanish } \\
\text { Constitution, The Rule of Law, and } \\
\text { The Separation of Powers }\end{array}$ \\
\hline $\begin{array}{l}\text { Community } \\
\text {; values/ } \\
\text { ideology }\end{array}$ & $\begin{array}{l}\text { Posts that strengthen the party and/ } \\
\text { or leader's values and ideology. Ap- } \\
\text { peal to emotions to create an image } \\
\text { of unity and to approach users who } \\
\text { identify with said values. }\end{array}$ & $\begin{array}{l}\text { Political tactics } \\
\text { and strategy }\end{array}$ & $\begin{array}{l}\text { Posts focusing on politicians' goals } \\
\text { in terms of building a certain kind } \\
\text { of government or on the scope for } \\
\text { political pacts with other parties to } \\
\text { form a government }\end{array}$ \\
\hline $\begin{array}{l}\text { Community: } \\
\text { personal life/ } \\
\text { backstage }\end{array}$ & $\begin{array}{l}\text { Posts in which parties or leaders } \\
\text { show a more human, personal at- } \\
\text { titude. Sharing private life (leisure } \\
\text { pursuits, hobbies, sport, etc.). }\end{array}$ & $\begin{array}{l}\text { Voting and } \\
\text { election } \\
\text { results }\end{array}$ & $\begin{array}{l}\text { Posts focusing on voting, election } \\
\text { results, polls and surveys. }\end{array}$ \\
\hline
\end{tabular}




\begin{tabular}{|c|c|c|c|}
\hline \multicolumn{2}{|r|}{ Function } & \multicolumn{2}{|r|}{ Theme } \\
\hline $\begin{array}{l}\text { Community: } \\
\text { fun }\end{array}$ & Posts focusing on user fun. & $\begin{array}{l}\text { Regional Model } \\
\text { of the Spanish } \\
\text { State }\end{array}$ & $\begin{array}{l}\text { Posts on the Spanish State's } \\
\text { regional organisation. }\end{array}$ \\
\hline Humour & Posts sharing jokes, memes, etc. & Terrorism & Posts on terrorism. \\
\hline $\begin{array}{l}\text { Courtesy } \\
\text { messages, } \\
\text { protocol }\end{array}$ & $\begin{array}{l}\text { Posts covering thanks, acknowledg- } \\
\text { ments, condolences, etc. }\end{array}$ & $\begin{array}{l}\text { Personal } \\
\text { subjects }\end{array}$ & $\begin{array}{l}\text { Posts covering politicians' personal } \\
\text { lives. }\end{array}$ \\
\hline \multirow[t]{7}{*}{ Others } & $\begin{array}{l}\text { Posts that do not fall under any of } \\
\text { the foregoing categories. }\end{array}$ & $\begin{array}{l}\text { Campaign } \\
\text { organisation }\end{array}$ & $\begin{array}{l}\text { Posts relating how various cam- } \\
\text { paign events (such as rallies, visits, } \\
\text { gatherings, etc.) are organised. }\end{array}$ \\
\hline & & $\begin{array}{l}\text { Relationship } \\
\text { with the media }\end{array}$ & $\begin{array}{l}\text { Posts sharing information on politi- } \\
\text { cians' appearances in the media. }\end{array}$ \\
\hline & & No theme & $\begin{array}{l}\text { Posts comprising emoticons or with } \\
\text { few words that do not cover any of } \\
\text { the themes listed and that it is hard } \\
\text { to guess what they are about. }\end{array}$ \\
\hline & & Foreign Policy & $\begin{array}{l}\text { Posts on the EU and other parts of } \\
\text { the world. }\end{array}$ \\
\hline & & $\begin{array}{c}\text { Political } \\
\text { Propaganda }\end{array}$ & $\begin{array}{l}\text { Posts similar to the campaign } \\
\text { slogans. }\end{array}$ \\
\hline & & $\begin{array}{l}\text { The Environ- } \\
\text { ment }\end{array}$ & $\begin{array}{l}\text { Posts on pollution, protecting fauna } \\
\text { and flora, global warming. }\end{array}$ \\
\hline & & Others & $\begin{array}{l}\text { Posts that do not fall under any of } \\
\text { the foregoing categories. }\end{array}$ \\
\hline
\end{tabular}


Table 3 Protocol for analysing visual resources

\begin{tabular}{|c|c|c|}
\hline \multicolumn{3}{|l|}{ Visual media } \\
\hline \multirow[t]{8}{*}{ Type } & \multicolumn{2}{|l|}{ Photo } \\
\hline & \multicolumn{2}{|l|}{ Selfie } \\
\hline & \multicolumn{2}{|l|}{ Mash-up } \\
\hline & \multicolumn{2}{|c|}{ Meme or sketch } \\
\hline & \multicolumn{2}{|l|}{ Video } \\
\hline & \multicolumn{2}{|l|}{ GIF } \\
\hline & \multicolumn{2}{|l|}{ Poster } \\
\hline & \multicolumn{2}{|l|}{ Graphic } \\
\hline \multirow[t]{11}{*}{ Context } & \multirow{3}{*}{ Personal } & Family: with friends and/or family. \\
\hline & & Leisure: engaging in leisure activities. \\
\hline & & Backstage: Backstage pictures of the campaign. \\
\hline & \multirow{5}{*}{ Electoral } & Rally: Leader and/or other politicians at a rally. \\
\hline & & Official visit: Leader and/or other politicians during an official visit. \\
\hline & & Debate: Leader and/or other politicians during a campaign debate. \\
\hline & & TV Spot: Pictures of campaign spots. \\
\hline & & Voting: Leader and/or politicians casting their votes. \\
\hline & \multirow{3}{*}{ Media } & Interview: Leader and/or other politicians giving an interview. \\
\hline & & Press Conference: Leader and/or other politicians giving a Press Conference. \\
\hline & & In situ: Leader and/or other politicians attending to the media. \\
\hline \multirow[t]{15}{*}{ Protagonist } & \multicolumn{2}{|l|}{ Leader. } \\
\hline & \multicolumn{2}{|c|}{ Leader and members of the party. } \\
\hline & \multicolumn{2}{|c|}{ Leader and members of other parties. } \\
\hline & \multicolumn{2}{|c|}{ Leader before the public (e.g. at a rally). } \\
\hline & \multicolumn{2}{|c|}{ Leader with citizens (e.g. posing with them, shaking hands, and so on). } \\
\hline & \multicolumn{2}{|c|}{ Leader and journalists/the media. } \\
\hline & \multicolumn{2}{|c|}{ Leader and non-political celebrities (sportsmen, musicians, writers, etc.). } \\
\hline & \multicolumn{2}{|c|}{ Leader and party staff (Press Director, volunteers etc.). } \\
\hline & \multicolumn{2}{|c|}{ Leader, friends and family. } \\
\hline & \multicolumn{2}{|c|}{ Party politicians other than the leader. } \\
\hline & \multicolumn{2}{|c|}{ Other party politicians with citizens. } \\
\hline & \multicolumn{2}{|c|}{ Politicians from other political parties with journalists/the media. } \\
\hline & \multicolumn{2}{|c|}{ Politicians from other political parties and non-political celebrities. } \\
\hline & \multicolumn{2}{|c|}{ Politicians from other political parties with party staff members. } \\
\hline & \multicolumn{2}{|c|}{ No people shown (landscapes, objects, etc.). } \\
\hline
\end{tabular}


Table 4 Functions of Facebook posts (in \%)

\begin{tabular}{|c|c|c|c|c|c|c|c|c|c|c|c|}
\hline Function & PPCV & Bonig & PSPV & Puig & Compr. & Oltra & Podem & Dalmau & Cs & Cantó & Vox \\
\hline Agenda & 7.69 & - & 31.82 & 6.67 & 4.76 & 21.05 & - & 10.71 & - & - & 25 \\
\hline $\begin{array}{l}\text { Manifesto or } \\
\text { promises }\end{array}$ & 11.54 & 9.52 & 13.64 & 26.7 & 9.52 & 21.05 & 7.14 & 3.57 & 45.4 & - & 12.5 \\
\hline $\begin{array}{l}\text { Political achieve- } \\
\text { ments in govern- } \\
\text { ment/opposition }\end{array}$ & 15.38 & 9.52 & 18.18 & 20 & 4.76 & 15.79 & 7.14 & 3.57 & 9.09 & - & - \\
\hline $\begin{array}{l}\text { Criticisms of } \\
\text { opponents }\end{array}$ & 42.31 & 38.10 & 4.55 & 13.3 & 28.57 & 10.53 & - & 10.71 & 27.3 & 45.45 & 18.7 \\
\hline Media information & 11.54 & 9.52 & - & - & - & - & 7.14 & - & - & - & 6.25 \\
\hline Interaction & - & - & - & - & - & - & - & - & - & - & - \\
\hline Participation & 7.69 & 9.52 & 13.64 & 20 & - & 15.79 & 21.43 & 32.14 & 9.09 & - & 9.37 \\
\hline $\begin{array}{l}\text { Community: values/ } \\
\text { ideology }\end{array}$ & - & 9.52 & 9.09 & 6.67 & 38.10 & 15.79 & 42.86 & 10.71 & - & 9.09 & 6.25 \\
\hline $\begin{array}{l}\text { Community: } \\
\text { personal life and } \\
\text { backstage }\end{array}$ & - & 4.76 & - & - & - & - & 7.14 & 7.14 & - & 9.09 & 3.12 \\
\hline Community: Fun & - & - & - & - & 4.76 & - & - & - & - & - & 3.12 \\
\hline Humour & - & - & - & - & - & - & - & - & - & - & 3.12 \\
\hline $\begin{array}{l}\text { Courtesy } \\
\text { messages/protocol }\end{array}$ & 3.85 & 9.52 & 4.55 & 6.67 & 9.52 & - & 7.14 & 21.43 & - & 27.27 & 6.25 \\
\hline Others & - & - & 4.55 & - & - & - & - & - & 9.09 & 9.09 & 6.25 \\
\hline
\end{tabular}

Source: The Authors.

users also gave many likes to those posts whose main purpose was to spur participation or to give thanks, as well as those showing aspects of the candidate's personal life or backstage glimpses of the campaign (33.33\% in all cases) (Table 5).

Thus while Instagram followers of PP, Vox, and Bonig were mainly interested in matters bearing on the course of the election campaign (such as agenda or electoral programme), followers of Ciudadanos and Cantó were more strongly attracted by content whose purpose was to forge a stronger, closer relationship with users.
When it comes to the parties in Government, the data show that there are no significant differences between users' reactions on the two social networks. The participation function spurred most 'likes' on both platforms when it came to parties and leaders. The only exception was Compromís' Facebook page (Table 4), where followers did not give any likes for contents that made use of this participation function.

Another of the functions chalking up most 'likes' in the case of parties/candidates in government concerned 'community values/ideology'. These are posts that 
Table 5 Functions of posts on Instagram (in \%)

\begin{tabular}{|c|c|c|c|c|c|c|c|c|c|c|c|}
\hline Function & PPCV & Bonig & PSPV & Puig & Compr. & Oltra & Podem & Dalmau & Cs & Cantó & Vox \\
\hline Agenda & 41.67 & 17.65 & 17.65 & 20 & 9.52 & - & 25 & 42.86 & - & - & 42.9 \\
\hline $\begin{array}{l}\text { Manifesto or } \\
\text { promises }\end{array}$ & 25 & 52.94 & 11.76 & 30 & 28.57 & - & 8.33 & 14.29 & - & - & 7.14 \\
\hline $\begin{array}{l}\text { Political achieve- } \\
\text { ments in govern- } \\
\text { ment/ opposition }\end{array}$ & 8.33 & 5.88 & 5.88 & 10 & 9.52 & 14.29 & - & - & 14.3 & - & - \\
\hline $\begin{array}{l}\text { Criticisms of } \\
\text { opponents }\end{array}$ & 16.67 & 5.88 & - & - & 9.52 & - & 8.33 & - & - & - & 14.3 \\
\hline Media information & - & - & 5.88 & - & - & - & - & - & - & - & - \\
\hline Interaction & - & - & - & - & - & - & - & - & - & - & - \\
\hline Participation & - & 5.88 & 23.53 & 20 & 19.05 & 57.14 & 16.67 & 28.57 & 28.6 & 33.33 & 14.3 \\
\hline $\begin{array}{l}\text { Community: } \\
\text { values/ideology }\end{array}$ & 8.33 & 11.76 & 35.29 & 10 & 14.29 & 14.29 & 16.67 & - & 14.3 & - & 14.3 \\
\hline $\begin{array}{l}\text { Community: } \\
\text { personal life and } \\
\text { backstage }\end{array}$ & - & - & - & - & - & 14.29 & - & - & - & 33.33 & - \\
\hline Community: Fun & - & - & - & - & - & - & - & - & - & - & - \\
\hline Humour & - & - & - & - & - & - & - & - & - & - & - \\
\hline $\begin{array}{l}\text { Courtesy } \\
\text { messages/protocol }\end{array}$ & - & - & - & 10 & - & - & 16.67 & - & 42.9 & 33.33 & - \\
\hline Others & - & - & - & - & 4.76 & - & 8.33 & 14.29 & - & - & 7.14 \\
\hline
\end{tabular}

Source: The Authors.

praise and boost the party's ideas and positioning with a view to making followers identify more closely with the political project. This function is especially relevant when this kind of post is used to convey ideas and collective beliefs to create a community of followers who are loyal to the party's values. In particular, this function was the one that got most likes on Facebook for Compromís (38.10\%) and Unides Podem (42.86\%), and on Instagram, for PSPV-PSOE (35.19\%).

The 'Agenda' and 'Manifesto and promises' functions (Tables 4 and 5) get a similar number of 'likes' as 'Community values/ideology'. This shows that while followers are interested in posts in which parties/candidates seek to get closer to voters, they also give many 'likes' to posts that bear directly on the campaign such as events or the electoral programme. Both functions are equally common among parties and leaders in the government. Nevertheless, one should note that in Puig's case, his followers on Facebook (26.7\%) and Instagram (30\%) mainly reacted to posts by the Valencian Regional Government's President. In those posts, he shared his proposals for a 'second term' were he to be re-elected. 
In relation to this last datum, one should note that the posts getting most 'likes' in the case of PSPVPSOE (18.18\%), Compromís (15.79\%), and Mónica Oltra $(15.79 \%)$,

on Facebook focused on the achievement of these parties and their leaders (Tables 4 and 5). Followers of Government parties were more interested in posts highlighting the measures taken and successes racked up in the previous legislature - something that obviously contrasted with followers of Opposition parties.

\section{Themes getting most 'likes' among Facebook and Instagram users}

With regard to themes, the data reveal that the kinds of posts getting the most likes followed the same pattern for both Facebook and Instagram users. Here, most of the 'likes' fell under just three heads: election results; social policy; campaign organisation and workings. In some cases, there were various factors at work in influencing these choices.

First, posts focusing on election results were those that got most 'likes' among followers of all the politicians with the exceptions of PP and Isabel Bonig. Maybe this should not come as a surprise, bearing in mind the party lost over 150,000 votes in the election and the number of seats it held in the Valencia Parliament plunged from 31 (2015 election) to 19 (2019). Looking at the differences among the users of Facebook and Instagram, the electoral results theme strongly influenced the Facebook followers of Compromís (33.33\%), Unides Podem (21.43\%), Vox (15.62\%), and Dalmau (17.86\%) and Cantó (18.18\%) (Table 5). On Instagram, the same theme strongly influenced followers of candidates for Compromís (42.86\%), PSPVPSOE (35.29\%), Ciudadanos (28.6\%), Oltra (57.14\%) and Puig (30\%) but was the second most important reason for giving 'likes' for followers of Unides Podem (33.33\%) and Dalmau (28.57\%) (Table 6).

The theme getting the second highest number of 'likes' was 'Social Policy', which was mainly found in traditional parties and leaders' posts. It was noteworthy that both the Facebook and Instagram followers of
PSPV-PSOE and of their candidate (and as was also the case with followers of Bonig (PP)) mainly 'liked' posts on this theme. Yet the use made of these posts differed between the two parties. In the case of posts by PSPV-PSOE and Puig, social issues were given a positive slant, with the focus on the government's political achievements. In Bonig's case, many of the candidate's posts criticised both the Government's failure to take action and the failure of those measures that it did take (Figure 1). In third place came the number of

\section{Figure 1 Example of posts on Social Policy}

Gorug Isabel Bonig
14 de abril . 6

Source: Facebook

'likes' for posts on the campaign organisation, which was directly conditioned by the collective-individual axis. Not surprisingly, this was more marked in the case of the party posts. Specifically, in the party posts on Instagram by the PP (58.33\%), Vox (42.86\%) and Unides Podem (41.67\%), almost half of the 'likes' were on posts covering the organisation of the various electoral events, drawing up candidate lists, and other campaign-related aspects. On Facebook, there were fewer posts on the theme than in Instagram, although here one should highlight PSPV-PSOE (36.36\%), Vox (28.12\%) and Compromís (21.05\%). With regard to leaders, only Dalmau's posts on Instagram elicited more reaction from followers (42.86\%). 
Table 6 Post themes in Facebook (in \%)

\begin{tabular}{|c|c|c|c|c|c|c|c|c|c|c|c|}
\hline Function & PPCV & Bonig & PSPV & Puig & Com. & Oltra & Pod. & Dalmau & Cs & Cantó & Vox \\
\hline Economy & 7.69 & 14.29 & 4.55 & - & - & 15.79 & - & 10.71 & 9.09 & - & - \\
\hline $\begin{array}{l}\text { Political \& } \\
\text { Social }\end{array}$ & 23.08 & 23.81 & 13.64 & 26.67 & 19.05 & 21.05 & - & 7.14 & 36.4 & - & 9.375 \\
\hline Culture \& Sport & 3.85 & - & - & 6.67 & - & - & - & - & - & 9.09 & 3.125 \\
\hline $\begin{array}{l}\text { Science \& } \\
\text { Technology }\end{array}$ & 3.85 & - & - & - & - & - & - & - & 9.09 & - & - \\
\hline Infrastructure & - & - & 4.55 & 6.67 & 4.76 & - & - & - & - & - & - \\
\hline Corruption & 15.38 & - & - & - & 4.76 & 5.26 & - & 3.57 & 9.09 & - & 3.125 \\
\hline $\begin{array}{l}\text { Democratic } \\
\text { Renewal }\end{array}$ & 7.69 & 14.29 & 4.55 & 26.67 & 4.76 & 10.53 & 64.29 & 21.43 & - & 9.09 & - \\
\hline $\begin{array}{l}\text { Political tactics } \\
\text { and strategy }\end{array}$ & 3.85 & 14.29 & 13.64 & 13.33 & 4.76 & 15.79 & - & 10.71 & 18.2 & 9.09 & - \\
\hline $\begin{array}{l}\text { Voting and } \\
\text { election results }\end{array}$ & - & 14.29 & 13.64 & 13.33 & 33.33 & 10.53 & 21.43 & 17.86 & - & 18.18 & 15.62 \\
\hline $\begin{array}{l}\text { Spain's } \\
\text { Regional Model }\end{array}$ & - & - & - & - & 4.76 & - & 7.14 & - & - & 27.27 & 3.12 \\
\hline Terrorism & - & - & - & - & - & - & - & - & - & 9.09 & 3.12 \\
\hline $\begin{array}{l}\text { Personal } \\
\text { themes }\end{array}$ & - & - & - & - & - & - & 7.14 & 7.14 & - & 9.09 & 6.25 \\
\hline $\begin{array}{l}\text { Campaign } \\
\text { Organisation }\end{array}$ & 19.23 & 4.76 & 36.36 & 6.67 & 4.76 & 21.05 & - & 14.29 & 9.09 & 9.09 & 28.12 \\
\hline $\begin{array}{l}\text { Media } \\
\text { Relations }\end{array}$ & 15.38 & 4.76 & - & - & - & - & - & - & - & - & 3.12 \\
\hline No theme & - & - & - & - & - & - & - & - & - & - & 9.37 \\
\hline Foreign Affairs & - & 4.76 & - & - & 4.76 & - & - & - & - & - & - \\
\hline $\begin{array}{l}\text { Political } \\
\text { Propaganda }\end{array}$ & - & - & - & - & - & - & - & - & - & - & - \\
\hline $\begin{array}{l}\text { The } \\
\text { Environment }\end{array}$ & - & 4.76 & 9.09 & - & 14.29 & - & - & - & 9.09 & - & 12.5 \\
\hline Others & - & - & - & - & - & - & - & - & - & - & 3.12 \\
\hline
\end{tabular}


Table 7 Post themes on Instagram (in \%)

\begin{tabular}{|c|c|c|c|c|c|c|c|c|c|c|c|}
\hline Theme & PPCV & Bonig & PSPV & Puig & Compr & Oltra & Podem & Dalmau & Cs & Cantó & Vox \\
\hline Economy & - & 5.88 & - & - & - & - & 8.33 & 14.29 & - & - & - \\
\hline Social Policy & 8.33 & 29.41 & 29.41 & 30 & 4.76 & 14.29 & - & - & 14.3 & - & 7.14 \\
\hline Sport \& Culture & 16.67 & 5.88 & 5.88 & 10 & - & - & - & - & - & 33.33 & - \\
\hline $\begin{array}{l}\text { Science \& Tech- } \\
\text { nology }\end{array}$ & 8.33 & - & - & - & - & - & - & - & - & - & - \\
\hline Infrastructure & - & - & - & - & - & - & - & - & - & - & - \\
\hline Corruption & - & - & - & - & - & - & - & - & - & - & - \\
\hline $\begin{array}{l}\text { Democratic } \\
\text { Renewal }\end{array}$ & - & - & 5.88 & - & 23.81 & - & - & - & 14.3 & - & - \\
\hline $\begin{array}{l}\text { Political Tactics } \\
\text { \& Strategy }\end{array}$ & - & 5.88 & - & 10 & 9.52 & - & 8.33 & - & 14.3 & - & 7.14 \\
\hline $\begin{array}{l}\text { Voting \& Elec- } \\
\text { tion Results }\end{array}$ & 8.33 & 11.76 & 35.29 & 30 & 42.86 & 57.14 & 33.33 & 28.57 & 28.6 & 66.67 & 7.14 \\
\hline $\begin{array}{l}\text { Regional Model } \\
\text { of The State }\end{array}$ & - & - & 5.88 & - & 4.76 & - & 8.33 & - & - & - & - \\
\hline Terrorism & - & - & - & - & - & - & - & - & - & - & - \\
\hline $\begin{array}{l}\text { Personal } \\
\text { themes }\end{array}$ & - & - & - & - & - & - & - & - & 14.3 & - & - \\
\hline $\begin{array}{l}\text { Campaign } \\
\text { organisation }\end{array}$ & 58.33 & 11.76 & 17.65 & 10 & 4.76 & - & 41.67 & 42.86 & - & - & 42.86 \\
\hline $\begin{array}{l}\text { Relationships } \\
\text { with the media }\end{array}$ & - & - & - & 10 & - & - & - & - & - & - & - \\
\hline No subject & - & 17.65 & - & - & - & 28.57 & - & 14.29 & - & - & 14.29 \\
\hline Foreign Affairs & - & - & - & - & 4.76 & - & - & - & 14.3 & - & - \\
\hline $\begin{array}{l}\text { Political } \\
\text { propaganda }\end{array}$ & - & - & - & - & - & - & - & - & 14.3 & - & - \\
\hline $\begin{array}{l}\text { The } \\
\text { Environment }\end{array}$ & - & 11.76 & - & - & 4.76 & - & - & - & - & - & 12.5 \\
\hline Others & - & - & - & - & - & - & - & - & - & - & 3.12 \\
\hline
\end{tabular}


When it comes to the general pattern for post themes garnering the most 'likes', one should also note that Unides Podem and Cantó on Facebook are the only cases where followers showed keen interest in subjects of 'Democratic Renewal' (64.29\%) and 'Spanish State's Regional Model' (27.27\%), respectively. These are posts that on the one hand argue the need for a change in Spain's current political system, and on the other, the desirability of a more federal organisation of the State. Above all, these posts criticise the current deadlock surrounding the issue of Catalan independence (Table 6). As both an emerging political party and emerging leader, both posed these issues as a way of distinguishing themselves from other political parties and politicians. This is why Unides Podem was strongly attracted to these themes.

\section{Visual media with most 'likes' among Facebook and Instagram users}

Ever since social networks began to be used for political communication, they have proven to be powerful tools for disseminating pictures (Russmann and Svensson, 2017). Instagram's approach forces all posters to use images in their posts, whether stills or videos. In Facebook's case, posters do not have to use images if they do not want to. Here, one should note that users of Facebook were particularly appreciative of posts that used pictures. With the exceptions of Ciudadanos (18.18\%), Vox (31.25\%), and PP (34.61\%), over half of all the posts getting the most 'likes' contained a photo, video, or other visual element (Table 8).

These data reveal that the reactions of Facebook users were shaped by the collective-individual axis and by the position that the political party and the leader held in Government. On the one hand, the followers of the Government parties were the ones who reacted most to posts containing visual media. On the other hand, the photos and videos used by Opposition leaders were the ones arousing the greatest interest among followers. Here, one should note that almost all the posts getting the most 'likes' in the cases of Cantó (100\%) and Bonig (90.47\%) were ones containing images. This revealed these two candidates' preference for visual media in forging links with their supporters and for building their political leadership.

Table 8 Posts with the most 'likes' containing visual
media in Facebook
\begin{tabular}{|l|l|l|l|}
\hline PSPV-PSOE & $81.81 \%$ & Puig & $53.33 \%$ \\
\hline Compromís & $90.47 \%$ & Oltra & $68.42 \%$ \\
\hline Unides Podem & $92.85 \%$ & Dalmau & $64.38 \%$ \\
\hline PP & $34.61 \%$ & Bonig & $90.47 \%$ \\
\hline Cs & $18.18 \%$ & Cantó & $100 \%$ \\
\hline Vox & $31.25 \%$ & & \\
\hline
\end{tabular}

Source: The Authors.

On the kinds of visual media found in posts with the most 'likes', the data reveal that photos are the preferred element on Instagram while video is what grabs most attention among Facebook users. In the latter social network, the only exceptions to the general preference for video are found among followers of PP, Vox and Ximo Puig, where posts containing photos got the best response (Table 9). Users on both platforms showed no interest whatsoever in selfies, GIFs, memes, and photo-montages. Only in the case of Compromís' Facebook page (21.05\%) and Instagram's Vox page $(21.43 \%)$ did posters featuring pictures and explanatory text elicit any interest from users (Table 9).

With regard to kinds of visual media, photos and videos showing candidates or other members of the party giving a rally speech were those that aroused most interest among followers in one or other of the social networks. This was particularly so in the case of parties, in which such images were used in roughly $50 \%$ of the posts getting most 'likes' (Table 10). The only exceptions to this rule were Compromís (10.53\% in Facebook and $28.57 \%$ in Instagram) and Unides Podem (23.08\% in Facebook), whose followers were also interested in visual content showing candidates or other party members in a debate or casting their votes at polling stations (Table 10). In the case of leaders, the 'likes' for pictures of rallies 
Table 9 Kinds of visual media generating most 'likes' on Facebook and Instagram (in \%)

\begin{tabular}{|c|c|c|c|c|c|c|c|c|c|c|}
\hline $\begin{array}{c}\text { Party / } \\
\text { Candidate }\end{array}$ & $\begin{array}{c}\text { Social } \\
\text { network }\end{array}$ & Photo & Selfie & $\begin{array}{c}\text { Mash- } \\
\text { up }\end{array}$ & Meme & Video & GIF & Poster & Screen & Graphic \\
\hline \multirow[t]{2}{*}{ PSPV-PSOE } & FB & 33.33 & - & - & - & 50 & - & 16.67 & - & - \\
\hline & IG & 58.82 & - & - & - & 35.29 & - & - & - & 5.88 \\
\hline \multirow[t]{2}{*}{ Compromís } & FB & 21.05 & - & - & 5.26 & 42.11 & - & 21.05 & 5.26 & 5.26 \\
\hline & IG & 38.10 & - & 4.76 & - & 33.33 & - & 4.76 & 4.76 & 14.29 \\
\hline \multirow[t]{2}{*}{ Unides Podem } & FB & 84.61 & - & - & - & - & - & 7.69 & - & 7.69 \\
\hline & IG & 75 & - & - & - & 25 & - & - & - & - \\
\hline \multirow[t]{2}{*}{ PP } & FB & 66.67 & - & - & 11.11 & 22.22 & - & - & - & - \\
\hline & IG & 91.67 & - & - & - & 8.33 & - & - & - & - \\
\hline \multirow[t]{2}{*}{ Ciudadanos } & FB & - & - & - & - & 100 & - & - & - & - \\
\hline & IG & 71.43 & - & - & - & 14.29 & - & - & - & - \\
\hline \multirow[t]{2}{*}{ Vox } & FB & 60 & - & - & 10 & 20 & - & 10 & - & - \\
\hline & IG & 64.29 & - & 7.14 & - & 7.14 & - & 21.43 & - & - \\
\hline \multirow[t]{2}{*}{ Puig } & FB & 75 & - & - & - & 25 & - & - & - & - \\
\hline & IG & 100 & - & - & - & - & - & - & - & - \\
\hline \multirow[t]{2}{*}{ Oltra } & FB & - & - & - & - & 100 & - & - & - & - \\
\hline & IG & 71.43 & - & - & - & 28.57 & - & - & - & - \\
\hline \multirow[t]{2}{*}{ Dalmau } & FB & 33.33 & - & 5.55 & - & 44.44 & - & 11.11 & - & 5.55 \\
\hline & IG & 100 & - & - & & - & - & - & - & - \\
\hline \multirow[t]{2}{*}{ Bonig } & FB & 36.84 & - & - & - & 52.63 & - & 10.52 & - & - \\
\hline & IG & 76.47 & - & - & - & 23.53 & - & - & - & - \\
\hline
\end{tabular}

were especially numerous on the social network pages for Bonig and Puig (Table 10). In the case of Oltra, Dalmau, and Cantó, such pictures proved less popular.

Visual media with personal content aroused little interest in users on both social networks. The few reactions to such videos and photos were mainly limited to followers of Unides Podem, Ciudadanos, Dalmau, Cantó, and Oltra. The same was true of the visual content of the posts, which mainly focused on leaders sharing their pastimes or backstage insights into the campaign. Only in Dalmau's case did some users react to posts in which he appeared together with his family (Figure 2). One can therefore say that that leaders and followers are just beginning to consider content in which politicians share their personal lives so as to forge stronger, warmer links with voters.

The protagonist is another key aspect of visual content. In all the posts studied, followers' showed greatest interest in three kinds of photos/videos, depending on their protagonists: (1) those showing only the regional leader; (2) those showing the regional leader together with other party members; (3) those showing 
Table 10 Context of the visual media generating most 'likes' on Facebook and Instagram (in \%)

\begin{tabular}{|c|c|c|c|c|c|c|c|c|c|c|c|c|c|}
\hline \multirow{2}{*}{$\begin{array}{c}\text { Party / } \\
\text { Candi- } \\
\text { date }\end{array}$} & \multirow[t]{2}{*}{ RRSS } & \multicolumn{3}{|c|}{ Personal } & \multicolumn{5}{|c|}{ Electoral } & \multicolumn{3}{|c|}{ Media-based } & \multirow{2}{*}{$\begin{array}{l}\text { Other } \\
\text { Others }\end{array}$} \\
\hline & & Fam. & Fun & $\begin{array}{l}\text { Back- } \\
\text { stage }\end{array}$ & Rally & Visit & $\begin{array}{l}\text { Deb- } \\
\text { ate }\end{array}$ & $\begin{array}{l}\text { TV } \\
\text { ad. }\end{array}$ & $\begin{array}{l}\text { Vot- } \\
\text { ing }\end{array}$ & $\begin{array}{l}\text { Inter- } \\
\text { view }\end{array}$ & $\begin{array}{l}\text { Press } \\
\text { Conf. }\end{array}$ & $\begin{array}{l}\text { In } \\
\text { situ }\end{array}$ & \\
\hline \multirow{2}{*}{$\begin{array}{c}\text { PSPV- } \\
\text { PSOE }\end{array}$} & $\mathrm{FB}$ & - & - & - & 55.56 & - & 5.56 & 16.8 & 16.8 & - & - & - & 5.56 \\
\hline & IG & - & - & - & 47.06 & 5.88 & - & 23.5 & 5.88 & - & 5.88 & 5.88 & 5.88 \\
\hline \multirow{2}{*}{$\begin{array}{l}\text { Com- } \\
\text { promís }\end{array}$} & $\mathrm{FB}$ & - & - & - & 10.53 & - & 26.32 & - & 26.32 & 5.26 & 10.53 & - & 21.05 \\
\hline & $I G$ & - & - & - & 28.57 & - & - & 4.76 & 9.52 & - & - & 4.76 & 52.38 \\
\hline \multirow{2}{*}{$\begin{array}{l}\text { Unides } \\
\text { Podem }\end{array}$} & $\mathrm{FB}$ & - & 7.69 & - & 23.08 & - & 23.08 & 15.4 & 23.08 & - & 7.69 & - & - \\
\hline & $I G$ & - & - & - & 41.67 & - & 16.67 & - & 33.33 & - & - & - & 8.33 \\
\hline \multirow[t]{2}{*}{ PP } & FB & - & - & - & 44.44 & 22.22 & 11.11 & 11.1 & 11.11 & - & - & - & - \\
\hline & IG & - & - & - & 66.67 & 33.33 & - & - & - & - & - & - & - \\
\hline \multirow{2}{*}{$\begin{array}{l}\text { Ciuda- } \\
\text { danos }\end{array}$} & FB & - & - & - & - & - & 50 & 50 & - & - & - & - & - \\
\hline & $I G$ & - & 14.3 & - & 42.86 & 14.29 & 14.29 & - & 14.29 & - & - & - & - \\
\hline \multirow[t]{2}{*}{ Vox } & FB & - & - & - & 60 & - & - & - & 10 & - & - & - & 30 \\
\hline & $I G$ & - & - & - & 42.86 & - & - & - & 7.14 & - & - & - & 50 \\
\hline \multirow[t]{2}{*}{ Puig } & $\mathrm{FB}$ & - & - & - & 50 & 12.5 & 12.5 & - & 25 & - & - & - & - \\
\hline & $I G$ & - & - & - & 30 & 10 & - & - & 20 & 10 & - & - & 30 \\
\hline \multirow[t]{2}{*}{ Oltra } & FB & - & - & - & 38.46 & - & 38.46 & 7.69 & 7.69 & - & - & - & 7.69 \\
\hline & IG & - & - & 28.57 & - & - & 14.29 & 28.6 & - & - & - & - & 14.29 \\
\hline \multirow{2}{*}{$\begin{array}{l}\text { Dal- } \\
\text { mau }\end{array}$} & $\mathrm{FB}$ & 5.55 & 5.55 & 5.55 & 22.22 & 11.11 & 22.22 & - & 16.66 & - & - & - & 11.11 \\
\hline & IG & - & - & - & 28.57 & 28.57 & - & - & 28.57 & 14.29 & - & - & - \\
\hline \multirow[t]{2}{*}{ Bonig } & $\mathrm{FB}$ & - & - & - & 36.84 & 21.05 & 15.78 & 10.5 & - & - & - & 10.52 & 5.26 \\
\hline & $I G$ & - & - & - & 52.82 & 11.76 & 17.65 & 5.88 & - & - & - & - & 5.88 \\
\hline \multirow[t]{2}{*}{ Cantó } & $\mathrm{FB}$ & - & - & 9.09 & - & - & 18.18 & - & 18.18 & 18.18 & - & - & 36.36 \\
\hline & $I G$ & - & 33.3 & - & - & - & - & - & 66.67 & - & - & - & - \\
\hline
\end{tabular}

Source: The Authors

the national leader, whether alone or accompanied by the regional leader. The number of 'likes' received in each case depended on sundry factors.

First, the visual media used in posts showing only the regional leader had an impact on their leadership status, whatever their position in the government, their track record or ideology. Here, one should note the strong interest shown by Instagram followers of Oltra (42.86\%) and Cantó (66.67\%) - roughly half the posts presented the two politicians as protagonists. Indeed, these two cases (and again for Oltra on 
Figure 2 Examples of personal publications
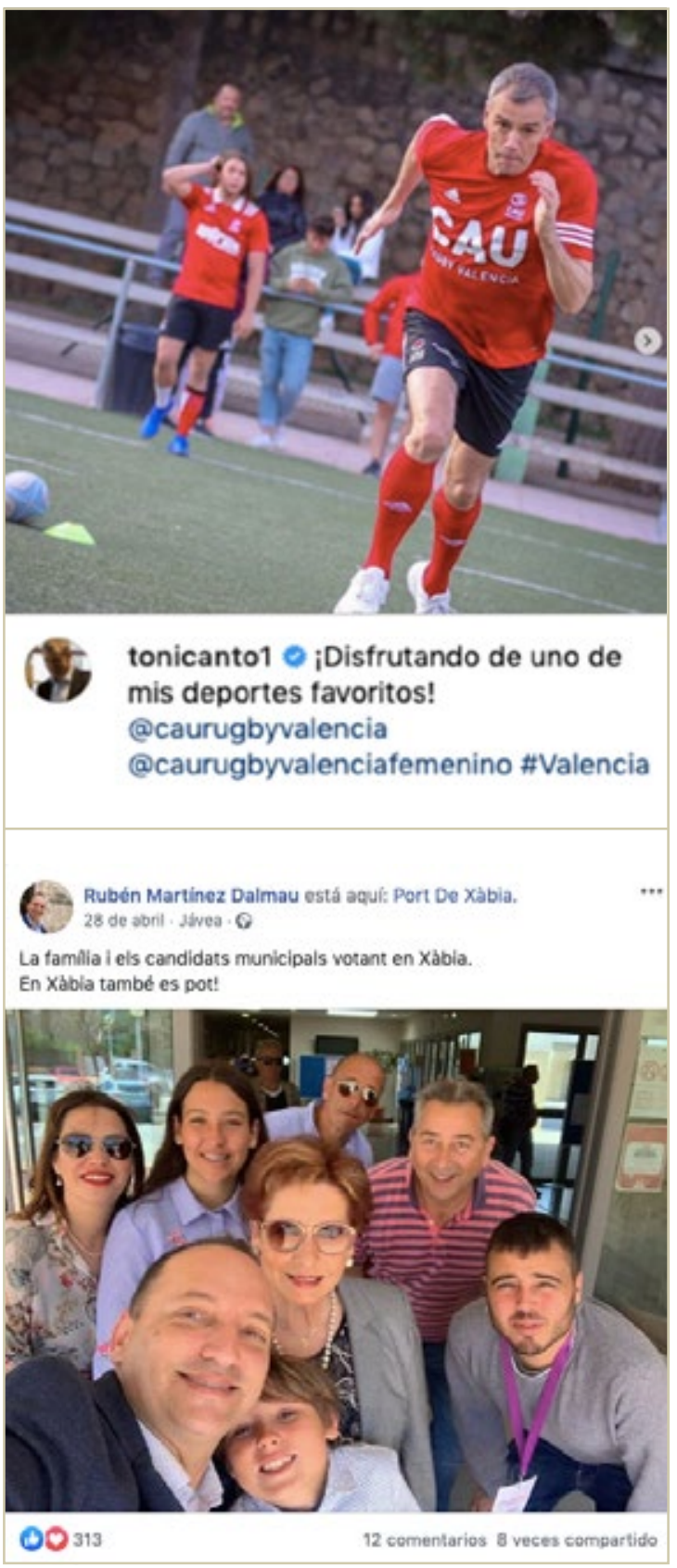

Source: Instagram and Facebook
Facebook) are the only ones in which the pictures of regional leaders aroused greater interest among users than pictures in which they were accompanied by other party members or by the national leader (Figure 3).

With regard to the impact of social media showing regional leaders being accompanied by other members of the party, once again there was a greater impact on candidate profiles (Figure 3). Dalmau's case stood out, where this kind of photo/video got twice as many 'likes' as those in which he only appeared as regional candidate $(57.14 \%$ versus $28.57 \%)$. The data showed that followers of Unides Podem reacted strongly to videos portraying a united party rather than just the leader on his own.

Last, visual content protagonised by national leaders on their own or accompanied by regional leaders boosted party profiles (Figure 3). The use of such content was striking in the case of traditional parties such as PSPV-PSOE (55.55\% in Facebook) and Compromís (47.62\% in Instagram), as well as in emerging parties such as Cs (42.86\% in Instagram) and Vox (50\% in Facebook). With regard to leaders, it was only in Puig's Instagram page that such content aroused much interest among users (30\%) (Figure 3). These data show that while followers of regional leaders reacted more favourably when the pictures/videos showed the leader as the focus, they were still more attracted by the national candidates, revealing the influential, central role played by the latter.

\section{Interaction resources getting the most likes among Facebook and Instagram users}

Both Facebook and Instagram offer diverse ways for fostering two-way communication. The best-known are mentions, hash tags, and links. These foster interaction and forge links among users. Apart from driving information-sharing, they also broaden information on a given theme or issue. Although they are both social networks, the data suggest that the interest aroused by politicians' posts varies between the two platforms. 
Figure 3 Posts with the most 'likes' depending on the visual media protagonist

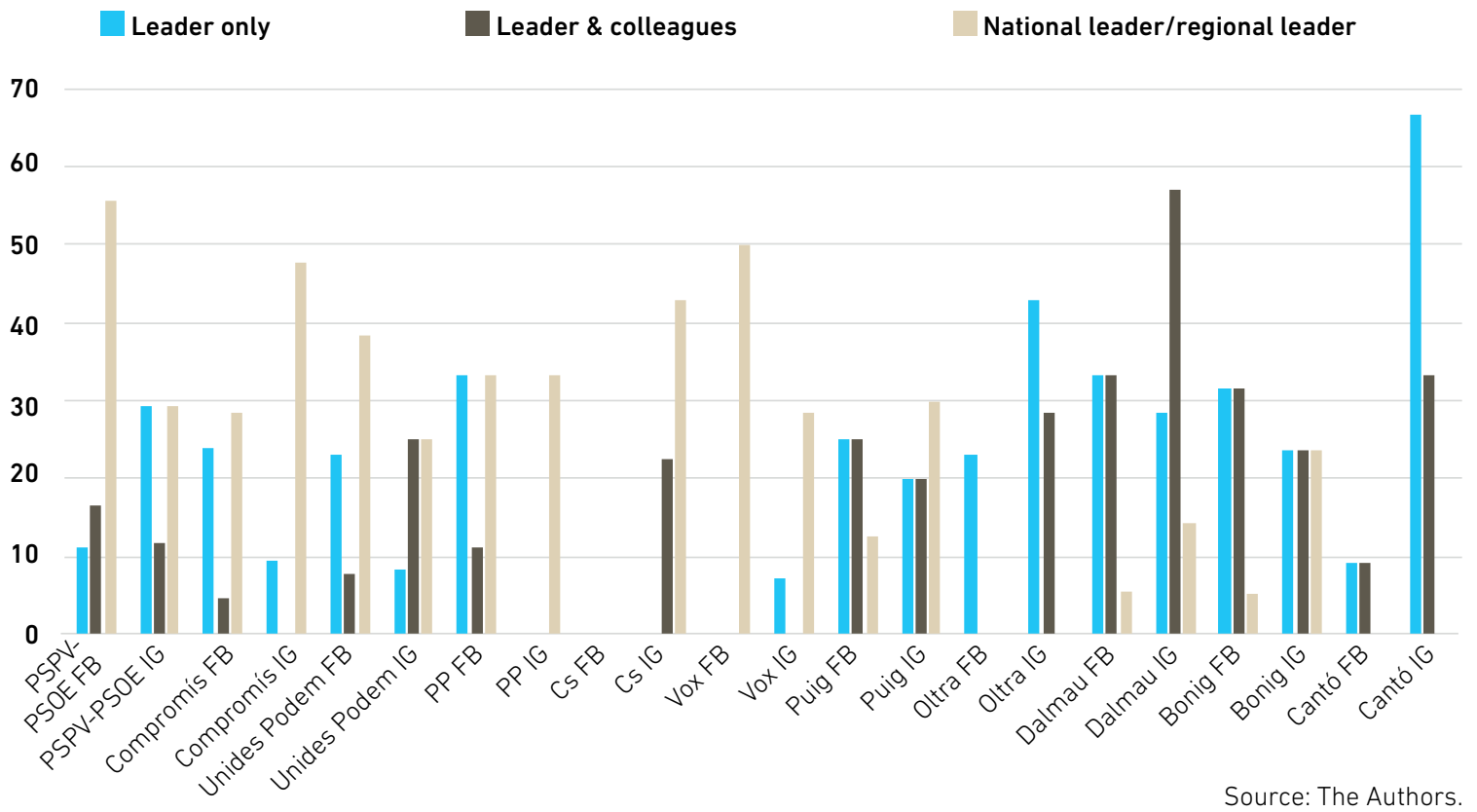

Thus posts including one or more mentions did not correlate with getting 'likes' since they hardly grabbed users attention. The only exception was in Toni Cantó's case, in which $66.67 \%$ of posts including this feature had led to a significant number of user 'likes'.

By contrast, the hash tag feature was generally popular with users. On Facebook, this feature was least popular on the Ciudadanos (9.09\%), Cantó (9.09\%), Compromís (14.29\%) and Dalmau (14.29\%) sites. For all politicians, user reaction to posts containing hash tags was significantly higher than ones without them. It was especially marked in the cases of Unides Podem, Cs, and PP Instagram accounts, where this feature appeared in every one of the posts that most grabbed users' attention (Table 11).

Last but not least, the use of links by parties and candidates also generated a fair number of 'likes' among the public (albeit to a lesser extent than was the case for hash tags). With the exception of Unides Podem on Instagram (7.15\%), all of the posts on this social network that used links got a percentage of 'likes' that ranged between $32 \%$ and $69 \%$ (Table 11). This shows that users took to the link feature.

When it came to the nature of the links, most of them linked to media web pages (independently of the politician covered). All of the links posted by Cs, PP, Unides Podem, Bonig, and Dalmau took users to the web pages of newspapers, TV and radio stations, and news agencies whose content bore directly on the party, the candidate or some other party member. This percentage was lower in the case of Compromís (42.85\%), PSPV-PSOE (42.85\%), Vox (77.27\%), Puig $(85.71 \%)$, and Oltra (84.74\%). In these cases, apart from media links there were also links that took users to one or more of the following: (1) other party social networks; (2) the networks of other members of the 
Table 11 Interactive tools in posts with the most 'likes' on Facebook and Instagram

\begin{tabular}{|c|c|c|c|c|c|c|c|}
\hline \multirow{2}{*}{$\begin{array}{c}\text { Party/ } \\
\text { Candidate }\end{array}$} & \multirow{2}{*}{$\begin{array}{c}\text { Social } \\
\text { net-work }\end{array}$} & \multicolumn{2}{|c|}{ Mention } & \multicolumn{2}{|c|}{ Hash tag } & \multicolumn{2}{|c|}{ Link } \\
\hline & & Sí & No & Sí & No & Sí & No \\
\hline \multirow[t]{2}{*}{ PSPV-PSOE } & $\mathrm{FB}$ & 9.09 & 90.91 & 27.27 & 72.73 & 31.82 & 68.18 \\
\hline & $I G$ & 35.29 & 64.70 & 83.35 & 17.64 & - & - \\
\hline \multirow[t]{2}{*}{ Compromís } & $\mathrm{FB}$ & 9.52 & 90.48 & 14.29 & 85.71 & 33.33 & 66.67 \\
\hline & IG & 28.57 & 71.42 & 90.47 & 9.52 & 19.05 & 80.95 \\
\hline \multirow[t]{2}{*}{ Unides Podem } & $\mathrm{FB}$ & 7.14 & 92.86 & 28.57 & 71.43 & 7.15 & 92.87 \\
\hline & IG & 33.33 & 66.67 & 100 & - & - & 100 \\
\hline \multirow[t]{2}{*}{ PP } & $\mathrm{FB}$ & 15.38 & 84.62 & 46.15 & 53.85 & 69.23 & 30.77 \\
\hline & IG & 33.33 & 66.67 & 100 & - & - & 100 \\
\hline \multirow[t]{2}{*}{ Ciudadanos } & $\mathrm{FB}$ & 18.18 & 81.82 & 9.09 & 90.91 & 81.82 & 18.18 \\
\hline & IG & 18.57 & 71.43 & 100 & - & - & 100 \\
\hline \multirow[t]{2}{*}{ Vox } & $\mathrm{FB}$ & 12.50 & 87.50 & 37.50 & 62.50 & 68.75 & 31.25 \\
\hline & IG & 28.57 & 71.43 & 85.71 & 14.29 & - & 100 \\
\hline \multirow[t]{2}{*}{ Puig } & $\mathrm{FB}$ & 13.33 & 86.67 & 40 & 60 & 46.67 & 53.33 \\
\hline & IG & 20 & 80 & 60 & 40 & - & 100 \\
\hline \multirow[t]{2}{*}{ Oltra } & FB & 10.53 & 89.47 & 15.79 & 84.21 & 36.84 & 63.18 \\
\hline & $I G$ & 28.57 & 71.43 & 42.86 & 57.14 & - & 100 \\
\hline \multirow[t]{2}{*}{ Dalmau } & $\mathrm{FB}$ & 3.57 & 93.43 & 14.29 & 85.71 & 35.71 & 64.29 \\
\hline & IG & 14.29 & 85.71 & 54.14 & 42.86 & - & 100 \\
\hline \multirow[t]{2}{*}{ Bonig } & $\mathrm{FB}$ & 19.05 & 80.95 & 57.14 & 42.86 & - & 100 \\
\hline & $I G$ & 23.53 & 76.47 & 70.59 & 29.41 & - & 100 \\
\hline \multirow[t]{2}{*}{ Cantó } & FB & 18.18 & 81.82 & 9.09 & 90.91 & - & 100 \\
\hline & IG & 66.67 & 33.33 & 33.33 & 66.67 & - & 100 \\
\hline
\end{tabular}

Source: The Authors

party, as in the cases of Compromís, Vox, PSPV-PSOE, Puig; (3) the party's web pages, as in Oltra's case. These data show the great store users still set by traditional media, which continue to play a key political communication role during election campaigns, even in today's digital setting. Thus, although users now use social networks to get information and to spread their views, they still have a strong interest in the content put out by newspapers, television and radio stations.

\section{CONCLUSIONS}

The study has four major findings that shed light on which items in politicians' posts elicit the most likes on Facebook and Instagram during an election campaign.

The first finding covers the answer to RQ1. The data showed that the posts by parties and leaders getting the most likes on both social networking platforms 
were generally those sharing information on the agenda and on manifesto proposals. In keeping with earlier findings in the literature, this indicates that politicians commonly use social networks to spread electoral information (Magin et al., 2017; López Meri et al., 2017). Furthermore, users showed great interest in this kind of content.

In answer to RQ2, the results indicate that the position occupied by the party and the leader in Government strongly determined the number of 'likes' given. In the case of Opposition politicians, followers reacted strongly to posts criticising or attacking opponents, especially those in Government. By 'liking' these posts, users reaffirmed their discontent over the Regional Government's measures and management. By contrast, followers of Government parties 'liked' posts praising the measures and the political successes racked up during the legislature rather than those attacking political opponents. Thus citizens use social networks to support the parties and leaders they follow. They express this support through 'likes' (among other ways), helping to spread the message. Similarly, participation is another function that gets a lot of 'likes' for Government parties and candidates. This participation involves users taking part in the various election events and in highlighting the party's values and ideology. The approach helps voters identify with the party's ideas and to forge a feeling of belonging to the same community (Giansante, 2015; Casero Ripollés, 2018).

The study's second major finding is that Facebook and Instagram users were strongly interested in three issues: (1) Social Policy; (2) Election results; (3) Campaign organisation (RQ1). Followers (especially in traditional parties) reacted strongly to posts on Education, Health, and other social rights. This revealed users' concern on issues directly affecting them as citizens. At the same time, many users also reacted to themes that were directly linked to the election campaign (such as voting results and the organisation of election events). This, as in the case of functions, shows that users were particularly interested in as- pects bearing on the election campaign. Such aspects mainly covered information on which events they could attend and where they could see their leaders and other party members. By contrast, the issues that got the strongest response from followers of emerging parties and leaders (such as Unides Podem, Dalmau, and Cantó) were those of democratic renewal, and Spain's regional model (RQ2).

The study's third major finding is that those posts that included visual media got more 'likes' (RQ1) - something that is also suggested in the previous literature (Viounnikoff-Benet, 2018; Svensson and Russmann, 2017; Fenoll and Hassler, 2019). While Instagram users showed particular interest in photos, the posts that shared videos were the ones that had the greatest impact on Facebook. By contrast, common tools in these social networks such as selfies, memes, and GIFs left users cold. Visual content revealing a candidate's professional role (for example, speaking at a rally, taking part in a debate, or making an official visit) made a bigger impact on users than content showing a candidate's private life and 'human' side. This is at odds with findings in previous literature, which indicated that the use of pictures/video showing politicians' private lives tended to strengthen links with users (Selva Ruíz and Caro Castaño, 2017).

The study's fourth major finding is that when it came to interaction tools, 'mentions' did not grab users' attention. This again is at odds with findings in earlier studies (Larsson, 2015). Indeed, one can go further and say that these tools hardly elicited any reaction from users. By contrast, posts containing hash tags and/or links made a big impact on users (Miquel Segarra et al., 2017). In this connection, the results showed that social media users still set great store by rallies, confirming the findings of earlier studies (Chadwick, 2013). In this respect, most of the links in posts getting the greatest number of 'likes' were to newspaper, TV and radio content (RQ1). This revealed that users combined the power of the digital setting with mainstream media offerings (Casero Ripollés et al., 2016). 


\section{BIBLIOGRAPHIC REFERENCES}

Abejón, P., Sastre, A. and Linares, V. (2012). Facebook y Twitter en campañas electorales en España. Disertaciones: Anuario electrónico de estudios en Comunicación Social, 5(7), 129-159.

Abejón Mendoza, P. and Mayoral Sánchez, J. (2017). Persuasión a través de Facebook de los candidatos en las elecciones generales de 2016 en España. El profesional de la información, 26(5), 928-936. DOI: 10.3145/ epi.2017.sep. 14

Alonso Muñoz, L. and Casero Ripollés, A. (2018). Political Agenda on Twitter during the 2016 Spanish Elections: Issues, Strategies, and Users' Responses. Communication \& Society, 31(3), 7-25.

Alonso Muñoz, L., Marcos García, S. and Casero Ripollés, A. (2016). Political Leaders in (inter)Action: Twitter as a Strategic Communication Tool in Electoral Campaigns. Trípodos, 39, 71-90.

Bentivegna, S. (2015). A colpi di tweet: La politica in prima persona. Bologna: Il Mulino.

Casero Ripollés, A. (2018). Research on Political Information and Social Media: Key Points and Challenges for the Future. El profesional de la información, 27(5), 964-974. DOI: 10.3145/epi.2018.sep.01

Casero Ripollés, A., Feenstra, R. A. and Tormey, S. (2016). Old and New Media Logics in an Electoral Campaign: The Case of Podemos and the two-way Street Mediatization of Politics. The International Journal of Press/ Politics, 21(3), 378-397. DOI: 10.1177/1940161216645340

Castillejo, B. and Semova, D. (2012). Elecciones generales y redes sociales en el caso de España, 2011. International Review of Information Ethics, 18, 144-149.

Cebrián Guinovart, E., Vázquez, T. and Olbarrieta, A. (2013). ¿Participación y democracia en los medios sociales? El caso de Twitter en las elecciones vascas de 2012. adComunica, 6, 39-63.

Chadwick, A. (2013). The Hybrid Media System: Politics and Power. New York: Oxford University Press. DOI: 10.1093/acprof:oso/9780199759477.001.0001

Christensen, H. S. and Bengtsson, Å. (2011). The Political Competence of Internet Participants: Evidence from Finland. Information, Communication \& Society, 14(6), 896-916. DOI: 10.1080/1369118X.2011.566931

Coromina, O., Prado, E. and Padilla, A. (2018). The Grammatization of Emotions on Facebook in the Elections to the Parliament of Catalonia 2017. El profesional de la información, 27(5), 1004-1011. DOI: 10.3145/epi.2018. sep.05

Díaz, J. B. (2014). Polarización política en las redes sociales. El caso español en el canal de comunicación Twitter. Estudio del debate del estado de la nación 2013. In A. R. Fernández Paradas (co-ord.), Interactividad y redes sociales (p. 95-114). Madrid: ACCI.

Di Bonito, I. (2014). El uso de Facebook durante las campañas electorales: Reflexiones sobre las elecciones catalanas de 2010 y 2012. Revista de la Asociación Española de Investigadores en Comunicación, 1(1), 26-34.

Enli, G. and Skogerbø, E. (2013). Personalized Campaigns in Party-centred Politics: Twitter and Facebook as Arenas for Political Communication. Information, Communication \& Society, 16(5), 757-774. DOI: 10.1080/1369118X.2013.782330

Fenoll, V. and Cano Orón, L. (2017). Participación ciudadana en los perfiles de Facebook de los partidos españoles: Análisis de comentarios en la campaña electoral de 2015. Communication \& Society, 30(4), 131-148.

Fenoll, V. and Hassler, J. (2019). ¿La red de los populistas? Diferencias en la campaña electoral en Facebook de España y Alemania. IC Revista Científica de Información y Comunicación, 16, 451-484. DOI: 10.12795/ IC.2019.i19.14

Fernández Muñoz, C. and Arceo Vacas, A. (2015). El papel de las redes sociales en la campaña electoral de los principales candidatos municipales y autonómicos madrileños en 2011: Claves desde el punto de vista de la comunicación de las organizaciones. Prisma Social, Revista de Ciencias Sociales, 14, 29-57.

Filimonov, K., Russmann, U. and Svensson, J. (2016). Picturing the Party: Instagram and Party Campaigning in the 2014 Swedish Elections. Social Media + Society, 2(3).

García, A., García, I. and Varona, D. (2012). Incidencia de las redes sociales vs. Cibermedios en las elecciones en España, 2011. Enl@ce: Revista Venezolana de Información, Tecnología y Conocimiento, 9(2), 11-29.

Gamir Ríos, J. V. (2016). Difusión online de las agendas partidistas en campaña electoral: El uso de internet en las elecciones locales de 2015 en la ciudad de Valencia (Tesis doctoral). Universitat de València, Comunidad Valenciana. 
Giansante, G. (2015). La comunicación política online. Barcelona: Editorial UOC.

Hootsuite (2019). Digital 2019: Global Digital Overview (2019). Source: https://datareportal.com/reports/digital-2019 -q2-global-digital-statshot.

Igartua, J. J. (2006). Métodos cuantitativos de investigación en comunicación. Barcelona: Bosch.

Jenkins, H. (2006). Convergence Culture: Where Old and New Media Collide. New York: NYU Press.

Jungherr, A. (2014). The Logic of Political Coverage on Twitter: Temporal Dynamics and Content. Journal of Communication, 64(2), 239-259.

Kreiss, D. (2012). Taking our Country back: The Crafting of Networked Politics from Howard Dean to Barack Obama. New York: Oxford University Press.

Kruikemeier, S. (2014). How Political Candidates Use Twitter and the Impact on Votes. Computers in Human Behavior, 34, 131-139.

Larsson, A. O. (2015). Comparing to Prepare: Suggesting Ways to Study Social Media Today and Tomorrow. Social Media Society, 1(1).

Lilleker, D. G., Tenscher, J. and Štetka, V. (2015). Towards Hypermedia Campaigning? Perceptions of New Media's Importance for Campaigning by Party Strategists in Comparative Perspective. Information, Communication \& Society, 18(7), 747-765.

López García, G. (2016). "Nuevos" y "viejos" liderazgos: La campaña de las elecciones generales españolas de 2015 en Twitter. Communication \& Society, 29(3), 149-167.

López García, G., Cano Orón. L. and Argilés Martínez, L. (2016). Circulación de los mensajes y establecimiento de la agenda en Twitter: El caso de las elecciones autonómicas de 2015 en la Comunidad Valenciana. Trípodos, 39, 163-183.

López Meri, A. (2016). Twitter-retórica para captar votos en campaña electoral: El caso de las elecciones de Cataluña de 2015. Comunicación y Hombre, 12, 97- 118.

López Meri, A., Marcos García, S. and Casero Ripollés, A. (2017). What Do Politicians Do on Twitter? Functions and Communication Strategies in the Spanish Electoral Campaign of 2016. El profesional de la información, 26(5), 795-804. DOI: 10.3145/epi.2017.sep.02

López Rabadán, P. and Doménech Fabregat, H. (2018). Instagram y la espectacularización de las crisis políticas: Las $5 \mathrm{~W}$ de la imagen digital en el proceso independentista de Cataluña. El profesional de la información, 27(5), 1013-1029. DOI: 10.3145/epi.2018.sep.06

López Rabadán, P., López Meri, A. and Doménech Fabregat. (2016). La imagen política en Twitter. Usos y estrategias de los partidos políticos españoles. Index Comunicación, 6(1), 165-195.

Magin, M., Podschuweit, N., Haßler, J. and Russmann, U. (2017). Campaigning in the Fourth Age of Political Communication. A Multi-method Study on the Use of Facebook by German and Austrian Parties in the 2013 National Election Campaigns. Information, Communication \& Society, 20(11), 1698-1719. DOI: 10.1080/1369118X.2016.1254269

Mancini, P. (2013). Media Fragmentation, Party System, and Democracy. The International Journal of Press/ Politics, 18(1), 43-60. DOI: 10.1177/1940161212458200

Marcos García, S. and Alonso Muñoz, L. (2017). La gestión de la imagen en campaña electoral. El uso de Instagram por parte de los partidos y líderes españoles en el 26J. In J. Sierra Sánchez, S. Liberal Ormaechea, (co-ord.), Uso y aplicación de las redes sociales en el mundo audiovisual y publicitario (p. 107-118). Madrid: McGraw-Hill.

Marcos García, S. and Alonso Muñoz, L. (2019). ¿Elecciones del cambio? Gestión estratégica de Twitter en los comicios municipales de Madrid 2015. In C. C. Flores Pérez, A. I. Arévalo Salinas and A. Barranquero Carretero, A. (ed.), Comunicación, cultura de paz e igualdad: Tejiendo ciudadanía comunicativa (p. 70-80). Zacatecas (Mexico): Universidad Autónoma de Zacatecas.

Marcos García, S., Alonso Muñoz, L. and Casero Ripollés, A. (2017). Usos ciudadanos de Twitter en eventos políticos relevantes: La \#SesiónDeInvestidura de Pedro Sánchez. Comunicación y Hombre, 13, 25-49.

McNair, B. (2011). An Introduction to Political Communication. New York: Routledge Taylor \& Francis.

Micó, J. L. and Casero Ripollés, A. (2014). Political Activism Online: Organization and Media Relations in the Case of 15M in Spain. Information, Communication \& Society, 17(7), 858-871. DOI: 10.1080/1369118X.2013.830634

Miquel Segarra, S., Alonso Muñoz, L. and Marcos García, S. (2017). Buscando la interacción: Partidos y candidatos en Twitter durante las elecciones generales de 2015. Prisma Social, 18, 34-54. 
Morozov, E. (2011). The Net Delusion: How not to Liberate the World. London: Penguin Books.

Parmelee, J. H. and Bichard, S. L. (2011). Politics and the Twitter Revolution: How Tweets Influence the Relationship between Political Leaders and the Public. Lexington Books.

Pérez, J. A., Peña, S., Genaut, A., Iturregui, L. and Mendiguren, T. (2014). Comunicación política en internet: Estrategias online de los partidos políticos vascos en las elecciones autonómicas de 2009. Mediateka, 14, 125-150.

Quevedo Redondo, R. and Portalés Oliva, M. (2017). Imagen y comunicación política en Instagram. Celebrificación de los candidatos a la presidencia del Gobierno. El profesional de la información, 26(5), 916-927. DOI: 10.3145/ epi.2017.sep.13

Quevedo Redondo, R., Portalés Oliva, M. and Berrocal Gonzalo, S. (2016). El uso de la imagen en Twitter durante la campaña electoral municipal de 2015 en España. Revista Latina de Comunicación Social, 71, 85-107. DOI: 10.4185/RLCS-2016-1085

Rahat, G. and Sheafer, T. (2007). The Personalization(s) of Politics: Israel, 1949-2003. Political Communication, $24(1), 65-80$

Rúas Araújo, X. and Casero Ripollés, A. (2018). Comunicación política en la época de las redes sociales: Lo viejo y lo nuevo, y más allá. adComunica. Revista Científica de Estrategias, Tendencias e Innovación en Comunicación, 16, 21-24. DOI: 10.6035/2174-0992.2018.16.2

Selva Ruiz, D. and Caro Castaño, L. (2017). Uso de Instagram como medio de comunicación política por parte de los diputados españoles: La estrategia de humanización en la "vieja" y la "nueva" política. El profesional de la Información, 26(5), 903-915. DOI: 10.3145/epi.2017.sep.12

Stromer Galley, J. (2014). Presidential Campaigning in the Internet Age. New York: Oxford University Press.

Svensson, J. and Russmann, U. (2017). Introduction to Visual Communication in the Age of Social Media: Conceptual, Theoretical and Methodological Challenges. Media \& Communication, 5(4), 1-5. DOI: 10.17645/ mac.v5i4.1263

Vaccari, C. (2017). Online Mobilization in Comparative Perspective: Digital Appeals and Political Engagement in Germany, Italy, and the United Kingdom. Political Communication, 34(1), 69-88. DOI: 10.1080/10584609.2016.1201558.

Viounnikoff-Benet, N. (2018). La imagen del candidato en la era digital: Cómo gestionar la escenografía política. Editorial UOC: Barcelona.

Zugasti Azagra, R. and Pérez González, J. (2016). Los temas de campaña en Twitter de @PPopular y @ahorapodemos para las elecciones europeas de 2014. adComunica. Revista Científica de Estrategias, Tendencias e Innovación en Comunicación, 12, 205-223. DOI: 10.6035/2174-0992.2016.12.12.

\section{BIOGRAPHICAL NOTE}

\section{Silvia Marcos García}

Associate Professor at Universitat Jaume I de Castelló. She holds a PhD in Communication Sciences, and graduated in Journalism. Marcos has a Master's Degree in New Trends and Innovation Processes in Communication from Universitat Jaume I. Marcos' work focuses on journalism and political communication in social networks.

\section{Nadia Viounnikoff-Benet}

She holds a PhD in Communication Sciences from Universitat Jaume I de Castelló. Viounnikoff-Benet holds a Bachelor's Degree in Advertising and Public Relations, and a Master's Degree in Political and Electoral Communication from Universitat Autónoma de Barcelona. Her work focuses on the study of the visual narrative of political leadership in election campaigns. 


\section{Andreu Casero Ripollés}

Casero is Full Professor of Journalism and Dean of the Humanities and Social Sciences at Universitat Jaume I. He graduated from Universitat Autònoma de Barcelona and was awarded a PhD from Universitat Pompeu Fabra. His research lines focus on political communication and digital transformation in journalism. He is a member of Institut d'Estudis Catalans. 